\title{
PSYCHOLOGICAL OPERATIONS AFTER THE SECOND WORLD WAR
}

\author{
LtCol Zbigniew Modrzejewski
}

\begin{abstract}
This paper has two purposes. From the personal side, the topic was chosen because I am interested in the history of psychological operations. To benefit the reader, I address psychological operations in selected military conflicts after the Second World War in order to consider this issue.

The goal of this study is to depict examples of the psychological operations conducted after World War II as part of military operations and examine the increasing importance of these issues to all involved in the battle. The article describes methods and means of psychological activities carried out by both sides in conflicts against both soldiers and civilians. Most attention in the article is devoted to the potential of the United States, which is without doubt a leader in the development of psychological operations. US PSYOP equipment is the most sophisticated and covers a broad spectrum of diverse technological means of influence. It results especially from the permanent engagement of US troops in military activities in various parts of the world after the end of World War II.

Psychological operations have been an essential element of warfare since ancient times. The purpose of psychological operations is to induce or reinforce foreign attitudes and behaviour favourable to the originator's objectives. It has been used throughout history to influence foreign groups and leaders. Moreover, psychological operations targeted the enemy's will to fight. In various conflicts after World War II, we can observe more and more attention being paid to psychological operations. Today we can observe arevolution in PSYOP capabilities. This is related to the development of modern technologies, especially the internet, which gives new opportunities for information transfer.
\end{abstract}

Keywords: psychological operations, media, audience, influence, dissemination 


\section{Introduction}

Nowadays, we should consider psychological operations as an integral part of military operations.

PSYOP may be conducted in both the long and short term across the full spectrum of military operations ${ }^{1}$. Modern PSYOP are enhanced by the expansion of mass communication capabilities (Internet, mobile phones, social media etc.).

To employ successful PSYOP it is essential to use effective communication techniques to convey the message to the target audience. The function of PSYOP is to use communication to influence behaviour² ${ }^{2}$.

Carl von Clausewitz said "killing the enemy's courage is as vital as killing his troops".

More of my favourite PSYOP quotes are included below:

"To capture the enemy's entire army is better than to destroy it; to take intact a regiment, a company, or a squad is better than to destroy them. For to win one hundred victories in one hundred battles is not the acme of skill. To subdue the enemy without fighting is the acme of skill".

Sun Tzu (544 B.C.-496 B.C.)

"There are but two powers in the world, the sword and the mind. In the long run the sword is always beaten by the mind".

Napoleon Bonaparte (1769-1821)

"The real target in war is the mind of the enemy command, not the bodies of his troops. If we operate against his troops it is fundamentally for the effect that action will produce on the mind and will of the commander; indeed, the trend of warfare and the development of new weapons - aircraft and tanks - promise to give us increased and more direct opportunities of striking at this psychological target".

\section{B.H. Liddell Hart (1895-1970)}

1 Allied Joint Doctrine for Psychological Operations AJP-3.10.1(B), SEPTEMBER 2014, p. 1-2.

2 G.L. Whitley, PSYOP operations in the 21 $1^{\text {th }}$ century, U.S. Army War College, Carlisle Barracks, Pennsylvania 2000, p. 13.

3 L.D. Harter, J. Sullivan, Propaganda Handbook, 20 th Century Publishing Company, Washington 1953, p. 198. 
"Machines don't fight wars. Terrain doesn't fight wars. Humans fight wars. You must get into the mind of humans. That's where the battles are won".

Col. John R. Boyd (1927-1997)

According to various sources, PSYOP is considered to be one of the key elements of Info Ops accompanied by Electronic Warfare (EW), Operations Security (OPSEC), Civil-Military Cooperation (CIMIC), Deception, Physical Destruction and many other activities ${ }^{4}$.

\section{Psychological operations - definitions and aims}

In order to examine the issue, providing a PSYOP definition is essential for further considerations.

Allied Administrative Publication defines psychological operations as: planned activities using methods of communication and other means directed at approved audiences in order to influence perceptions, attitudes and behaviour, affecting the achievement of political and military objectives ${ }^{5}$.

According to the Polish doctrinal document "Operacje Psychologiczne DD/3.10.1(A)": psychological activities are a complex planned activities during peace, crisis and war time, directed at hostile, friendly and neutral audiences influencing their attitudes and behaviour in order to achieve desired by the leader political and military objectives. They are implemented in the country and outside its border, in areas of responsibility and interest of commands and staffs at all levels. They can be run independently or as a part of NATO or other coalition combined operation ${ }^{6}$.

The US uses the term Military Information Support Operations (MISO) to replace the term psychological operations appropriately, which more accurately reflects and conveys the nature of planned peacetime or combat operations activities.

4 Allied Joint Doctrine for Information Operations AJP-3.10 (A), DECEMBER 2015, p.1-10.

5 AAP-06 (2014) NATO Glossary Terms and Definitions, NSA, 29 April 2014, 2-P-10.

6 Operacje psychologiczne DD/3.10.1 (A), Sztab. Gen., Warszawa 2010, p. 10. 
They define MISO as: planned operations to convey selected information and indicators to foreign audiences to influence their emotions, motives, objective reasoning, and ultimately the behaviour of foreign governments, organizations, groups, and individuals in a manner favourable to the originator's objectives?

Psychological operations take place throughout the tactical, operational, and strategic environments and, as a consequence, we can distinguish three categories of military PSYOP: strategic, operational and tactical.

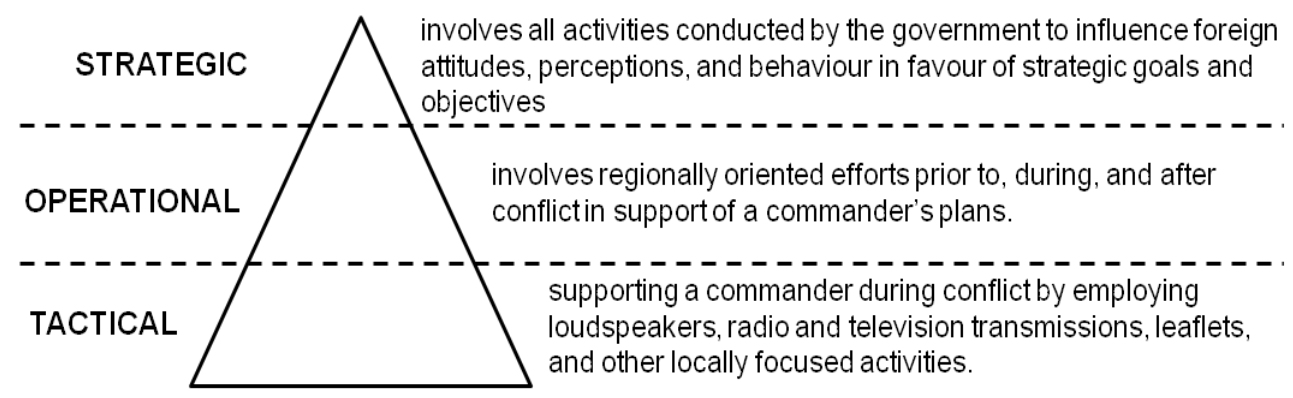

Figure 1. Categories of military psychological operations

PSYOP activities can create a supportive atmosphere and a willingness to cooperate by influencing target audience behaviour, attitudes and perception to support mission objectives.

Our national doctrinal document identifies three main objectives of psychological operations:

1) weakening of the will to act and the aggressive intentions of the opposite or potentially opposite target audiences;

2) strengthening the commitment and support from friendly target audiences;

3) obtaining support and cooperation from uncommitted or undecided communities.

Various methods are used to deliver PSYOP products to target audiences. It depends on the resources and measures for disseminating them.

7 Joint Publication JP-3-13.2 Military Operation Support Operations, Joint Chiefs of Staff,

07 January 2010 Incorporating Change 120 December 2011, GL-4.

8 Operacje psychologiczne ..., op. cit., p. 14. 


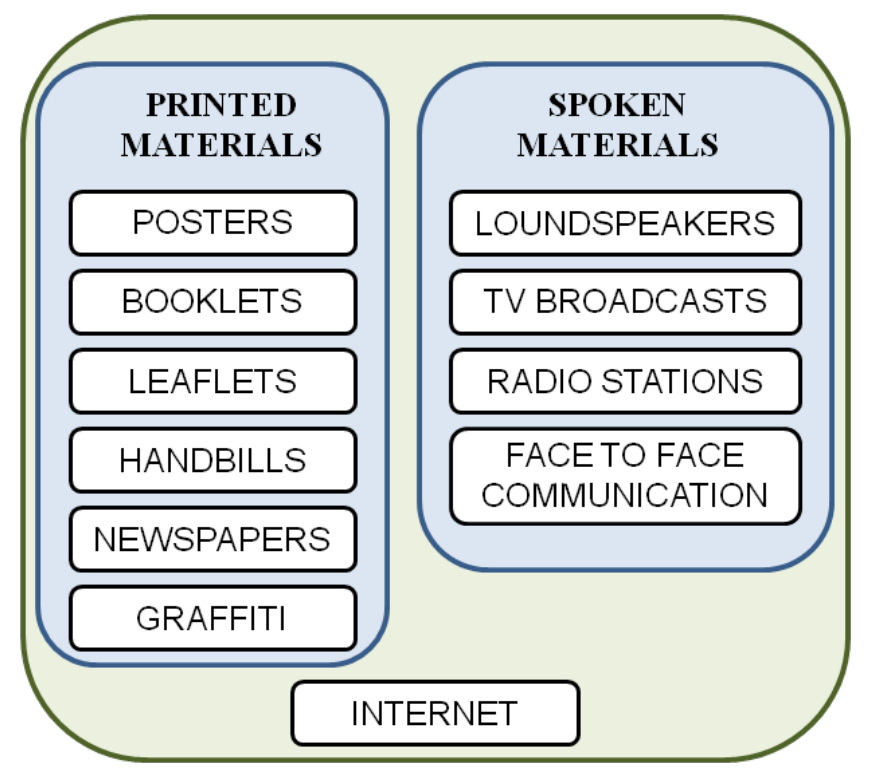

Figure 2. Common methods of delivering messages

There are three basic categories of PSYOP products: audio, visual and audiovisual. At the tactical level, messages are usually delivered by loudspeaker and face to face communication. For more deliberate campaigns, leaflets, radio or television may be used. Furthermore, radio or television broadcasts and various publications may be used during strategic operations. However, in modern times, the internet plays a vital role in psychological warfare campaigns (see conflict in the Ukraine). The internet provides access to information through a variety of means, including worldwide websites, social media, chats, interactive TV etc. In the following section, I will give several examples of the mentioned methods in subjectively chosen conflicts

\section{Psychological operations during the Korean War (1950-1953)}

The Korean War began on $25^{\text {th }}$ June 1950, when North Korean forces invaded South Korea. Psychological operations were used extensively during this war. At the beginning, both sides conducted psychological activities accusing each other of aggression. The first and the greatest problem for US PSYOP officers in conducting 
psychological operations in Korea was to identify the mind and character of the target audience. It was especially difficult because of wide differences between the cultures of the East and of the West.

During the operation, each side employed psychological operations to try to convince the soldiers of the other side to lay down their arms, surrender to the enemy, or to spread confusion and reduce morale. Another aim of PSYOP was to discourage local civilians from aiding the opponent army of the other side by providing food or billeting and to discredit the enemy in the eyes of civilians.

American specialists began radio broadcasts and leaflet drops over the Republic of South Korea immediately after North's Korea's invasion across the $38^{\text {th }}$ Parallel in June 1950.

The most common method was dropping leaflets or flyers on territory held by enemy troops.

They used different types of leaflets. The first type of leaflet was a warning against UN air attack. The leaflets, meant for civilians, directed them to stay away from roads, railways, and other military targets.

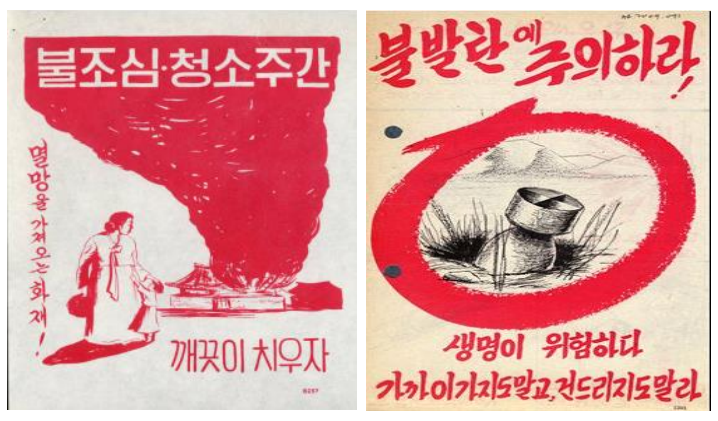

Source: http://www.digitalhorizonsonline.org (left), http://www.nationalmuseum.af.mil (right), 31 January 2017.

\section{Figure 3. Examples of the leaflets}

On the left we can see a fire prevention - clear up poster. It shows a Korean woman and a child with a burning home in the background. The leaflet on the right warned civilians to stay away from unexploded bombs and military targets like main highways, railroads and military factories. 
The other main type of leaflets portrayed the people of North Korea as pawns of the Korean, Chinese, and Soviet Communists. These leaflets blamed Kim II Sung, Mao Tse Tung and Joseph Stalin for lying to the Korean people and prolonging the war. The United States Psychological Warfare Division also employed patriotic music leaflets. Moreover, photos of happy prisoners of war were used successfully on many propaganda leaflets.

Those aimed at soldiers tried to instill fear by warning that the only escape from the "Flying Tigers of the Free World" was to surrender.

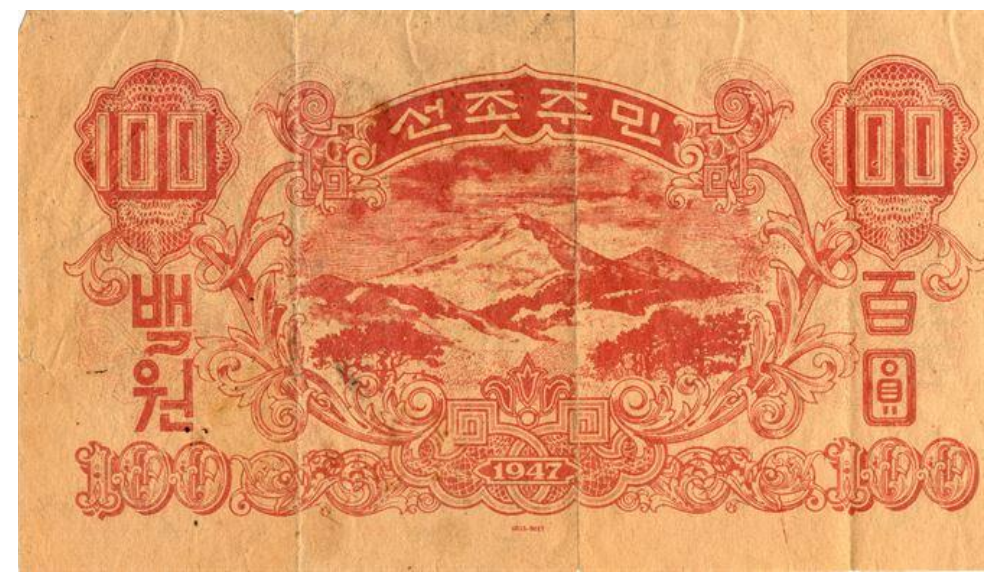

Source: http://www.nationalmuseum.af.mil, 06 February 2017.

\section{Figure 4. Safe certificate}

The certificate dropped by Air Force aircraft shown above promised enemy soldiers safe passage through UN lines if they surrendered. One side of this looked like a North Korean 100 Won bill, which would entice an enemy soldier to pick it up. The other side had instructions written in Korean, English and Chinese.

According to a press release from Cheonggyecheon Museum, the Communist side dropped 300 million flyers, while the United Nations dispersed 2.5 billion .

9 PsyWar: an exhibition of Korean War propaganda leaflets, http://www.korea.net/ NewsFocus/Society/view?articleId=81778, 31.01.2017. 
Furthermore, US troops used some psychological warfare military transport aircraft - Douglas C-47, which were equipped with powerful speakers to broadcast propaganda over the enemy's positions.

\section{Psychological operations in Vietnam (1956-1975)}

Psychological operations were also extensively used in Vietnam. The $4^{\text {th }}$ Psychological Operations Group (4 POG) provided tactical support for allied operations and took part in strategic campaigns against North Vietnam. Nowadays, the 4th Psychological Operations Group of the US Army is an active psychological operations unit located at Fort Bragg, North Carolina. It deploys anywhere in the world on short notice for all levels of conflict.

During its service in Vietnam, the organisation of the $4^{\text {th }}$ POG was completely different. The four battalions of the group were divided by geographic regions. The $6^{\text {th }}$ PSYOP Battalion was stationed at Bien Hoa and provided services to the tactical units, both American and Vietnamese, and to the various political entities such as provinces and cities in the area of III Corps. The $7^{\text {th }}$ PSYOP Battalion was stationed in Da Nang and provided service to I Corps. The $8^{\text {th }}$ PSYOP Battalion was based at Nha Trang, but one of its field teams (B Company) was based out of Pleiku nearly 100 kilometres away. The 8th Battalion served the II Corps area of Vietnam. The $10^{\text {th }}$ PSYOP Battalion was stationed in Can Tho and served IV Corps.

$8^{\text {th }}$ PSYOP Battalion advisory team assisted Vietnamese radio broadcasters in programming PSYOP messages to hundreds of thousands of Vietnamese civilians, North Vietnamese soldiers and Viet Cong. 8th PSYOP Battalion radio technicians manned the Group's 50-thousand watt transmitter from its hilltop site outside Pleiku City. In connection with the operation, PSYOP aircraft dropped thousands of small transistor radios to Viet Cong and North Vietnamese Army troops. All were pre-tuned to the station's frequency. The 8th PSYOP Battalion provides PSYOP support for all of the II Corps. To provide adequate coverage in Vietnam's largest corps it became necessary to detach one of its companies from its headquarters in Nha Trang and station it permanently in Pleiku. The Nha Trang and Pleiku elements had printing and field team capabilities. The company at Pleiku also maintained a small PSYOP Development Center (PDC), which was 
an extension of the Group PDC system. On March 1968, The Viet Cong sent about 20 sappers against the radio station and destroyed the radio tower ${ }^{10}$.

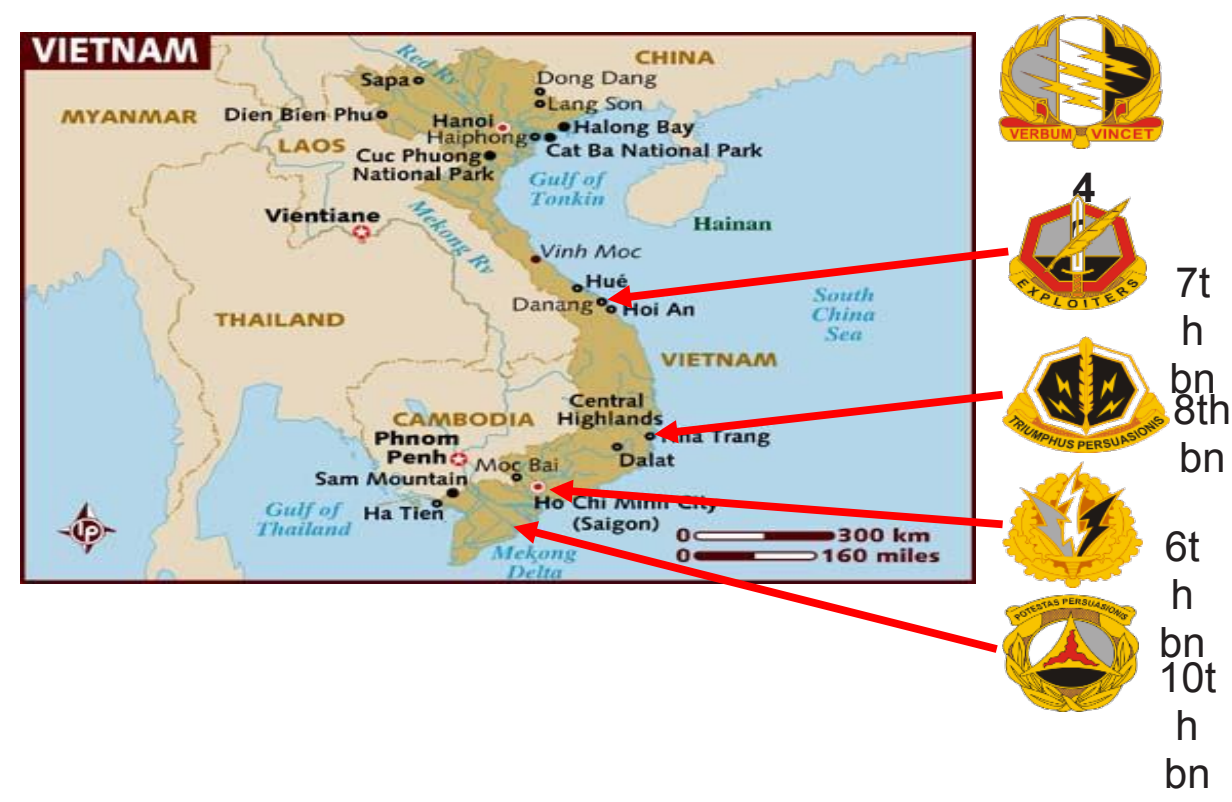

Figure 5. Location of 4th Psychological Operations Group in Vietnam

$4^{\text {th }}$ POG were not alone in participating in psychological activities in Vietnam. "Quick Speak" was the project name for the psychological operations (PSYOP) of the USAF 5th Air Commando Squadron which consisted of sixteen single engine U-10s and four C-47s, all equipped with 3000 watt loudspeaker systems and leaflet dispenser chutes. During the first six months of 1966, the squadron dropped more than 508 million leaflets. The leaflets urged the Viet Cong to surrender to Government forces, promising them good treatment and eventual repatriation to their families. The biggest single operation of project "Quick Speak" was its Tet programme in January. More than 103 million leaflets were dropped and 380 hours of speaker broadcasts were flown in an effort to exploit the natural desire of Viet Cong and North Vietnamese soldiers to be with their families during Tet, the nation's most important holiday season.

10 http://timyoho.net/BVApage/7thPsyOp/Merkle-KIA-Accounts.html, 19.02.107. 
The most popular U.S. psychological activity was leaflet dissemination. The Joint United States Public Affairs Office (JUSPAO) was the main proponent of leaflets and specified the main objectives of campaign which were clarified and amplified by 1968 :

1. To convince the people of North Vietnamese that the bombing was in selfdefence for communist attacks in the South.

2. To convince the people that the Americans and South Vietnamese had humanitarian concern for people of North Vietnam.

3. To convince the people of the North that it was in their best interests to oppose the war.

4. To keep the people and the government informed of the policies of the USA and republic of Vietnam.

5. To reduce confidence in the USSR and the China as faithful allies.

6. To condition soldiers to think about the Chieu Hoi ("Open Arms") programme as a way to escape hardship and death.

7. To discredit the Hanoi regime.

The targets of the campaign were the general population, the armed forces, the party cadre and the leadership of communist Party.

The opposite side also conducted some psychological activities. Early in the war, all of the Viet Cong leaflets were simply hand- written text with very short messages.

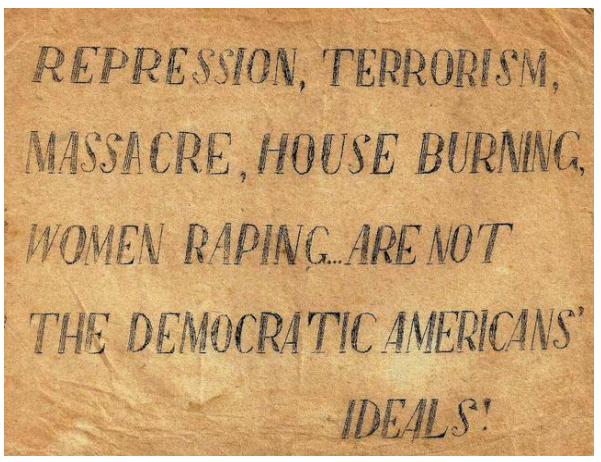

Source: http://www.psywarrior.com, 04 February 2017.

Figure 6. A very early Vietnam propaganda leaflet 
As the Vietnam War went on for a decade, the Viet Cong leaflets became more intricate, political and colourful and the messages got far more technical with references to American politicians and peace marches at home.

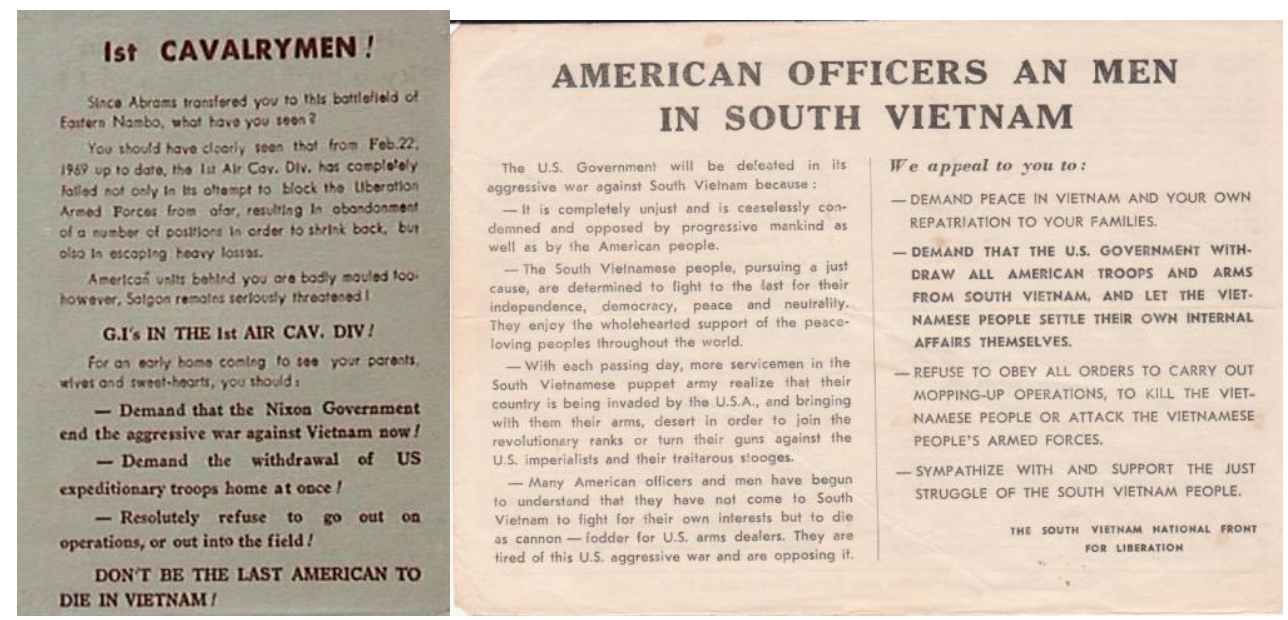

Source: http://museum.vhpa.org/propaganda/propaganda.shtml (left), http://www.usmilitariaforum. com (right), 04 February 2017.

\section{Figure 7. Viet Cong propaganda leaflet}

The enemy forces in Vietnam were rarely exposed to sustained air, artillery or other military attack. Communist commanders largely held the initiative for determining the time and place of a battle, the Viet Cong and North Vietnamese Army (NVA) forces were able, for the most part, to control their own combat exposure and casualties. Most engagements were short-lived, and most communist units fought only a few times a year. As a result of these combat conditions, U.S. and Government of South Vietnam forces never caused a catastrophic break in communist morale or an en masse surrender of a large-sized enemy main force unit. Even though the U.S. and Government of South Vietnam mounted massive PSYOP campaigns involving billions of leaflets and tens of thousands of hours of aero broadcasts to induce enemy defections and surrenders, the number of mainforce prisoners and defectors that came into allied hands was minuscule compared with the number of enemy troops engaged and killed during the conflict ${ }^{11}$.

11 S.T. Hosmer, Psychological effects of. U.S. Air Operations in Four Wars 1941-1991: Lessons for U.S. Commanders, Santa Monica, California 1996, pp. 125-129. 
To conclude, during the war in Vietnam, PSYOP specialists used three main types of psychological influence on the enemy: printed materials, via radio and by electro acoustic measures. For obvious reasons, the usage of television would have been at that time unreasonable. However, in later years, its potential impact has been fully appreciated (especially the concepts of impact on the population in the occupied territories and against prisoners of war in the camps).

\section{Psychological operations in The Former Yugoslavia (1995-1999)}

NATO's Balkan multinational operations under the codename Operation Enduring Freedom started as a peace enforcement mission with the deployment of the Implementation Force (IFOR) into Bosnia on $20^{\text {th }}$ December 1995 and lasted for one year. IFOR was a 60000 person, 36 nation coalition force. Many of the national forces earmarked for IFOR, mainly the French and British, were already in Bosnia as a part of the United Nations Protection Force (UNPROFOR). On $21^{\text {th }}$ December 1996, the task of IFOR was taken over by thee Stabilisation Force (SFOR) and the military operation continued mainly as a peacekeeping mission.

Furthermore, NATO has been leading a peace-support operation in Kosovo since June 1999 in support of wider international efforts to build peace and stability in the area - the Kosovo force (KFOR). KFOR was established when NATO's 78-day air campaign against Milosevic's regime, aimed at putting on end to violence in Kosovo, was over.

Since December 1995, over 1000 soldiers from the U.S. Army's Civil Affairs and Psychological Operations Command (USACAPOC) have supported IFOR and SFOR in the former Yugoslavia. The PSYOP component to this mission represents one of the largest and most comprehensive PSYOP missions in U.S. history.

The PSYOP campaign was designed to influence the local population and the former warring factions to cooperate with NATO activities. To achieve these goals, the task force launched a multimedia campaign, albeit a limited one, and sought to use step by step psychological processes to entice attitudinal changes. To accomplish this, the Combined Joint Psychological Operations Task Force 
(CJPOTF) oversaw the operation of 34 subordinate organisations including theatre, divisional and brigade support elements as well as tactical PSYOP teams ${ }^{12}$.

Psychological operations played a key role during operation Allied Force. The IFOR/SFOR information campaign was massive both in terms of the quantity of materials disseminated and the variety of themes explored during the operation. Since December 1995, the Combined Joint IFOR Information Campaign Task Force (CJIICTF) has produced and disseminated close to 12 million products within the Federation of Bosnia and the Republic of Srpska. This includes handbills, pamphlets, posters, the Herald of Peace (a weekly IFOR newspaper focusing on news and features of national interest), the Mirko teen-oriented magazine, as well as various radio, television, and miscellaneous products such as soccer balls, colouring books, and IFOR/SFOR logo pens ${ }^{13}$.

By December 1996, with the transition from IFOR to SFOR, the PSYOP task force organisation had changed slightly. The headquarters and Product Development Cell (PDC) became multinational instead of all-U.S. with French and British liaison officers assigned to the Combined Joint Information Task Force headquarters. The British-led division acquired some printing equipment in spring 1996 to develop products specific for its area of responsibility.

The primary mission of IFOR and SFOR Psychological Operations was to deter armed resistance and hostile behaviour against IFOR/SFOR troops and operations. The Allies also produced mine-warning leaflets. More than 104.5 million leaflets were dropped throughout Serbia over the course of the campaign. Perhaps the most interesting is the mine-warning 12-page Superman comic book entitled "Deadly Legacy".

There were a number of magazines and newspapers published by the Allied forces. For example, US forces in Sarajevo published a weekly news magazine called Herald of Peace (under SFOR this became the Herald of Progress). British forces in Banja Luka printed a magazine called Mostovi. The German forces in Sarajevo published a monthly magazine for teenagers entitled Mirko.

12 http://www.psywarrior.com/bosnia.html, 06 February 2017.

13 See M.R. Jacobson, Tactical PSYOP Support to Task Force Eagle, The National Defense University, 1997, p. 194-195. 

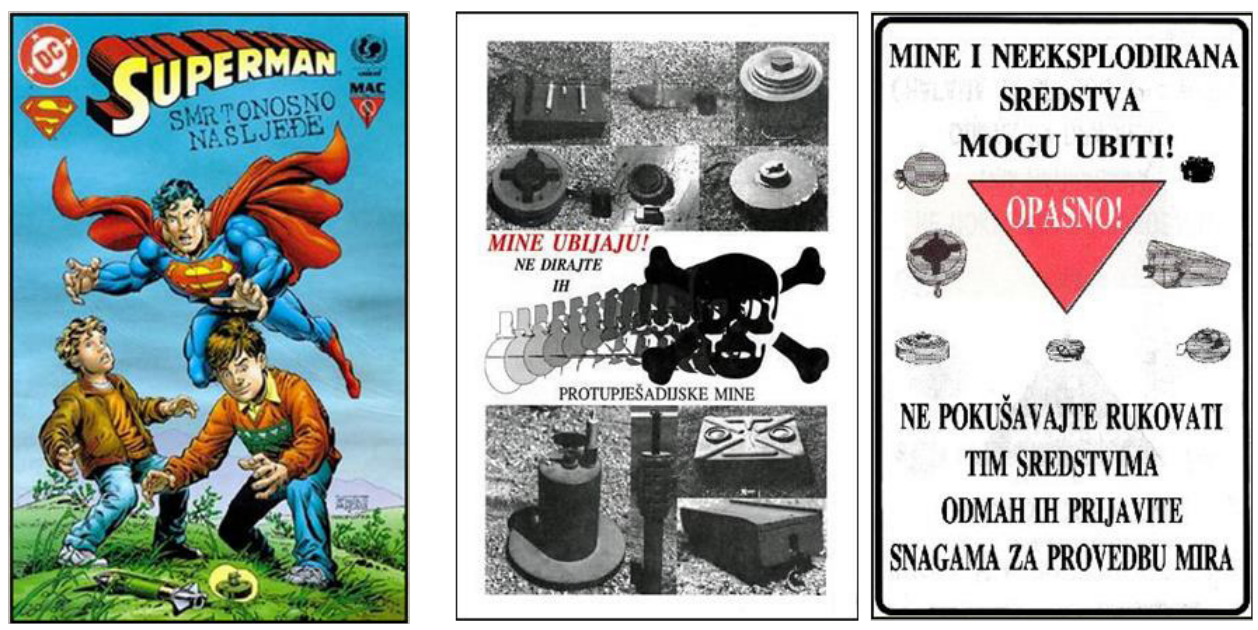

Figure 8. Mine warning products

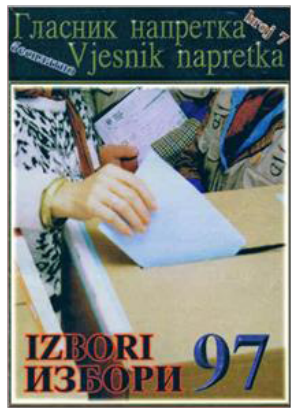

The Herald of Peace

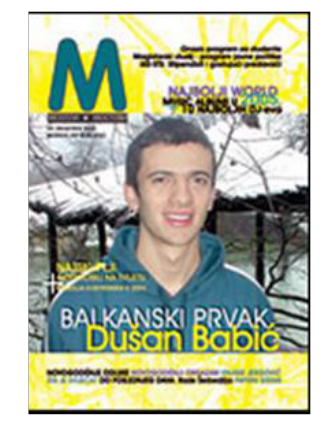

British magazine MOSTOVI

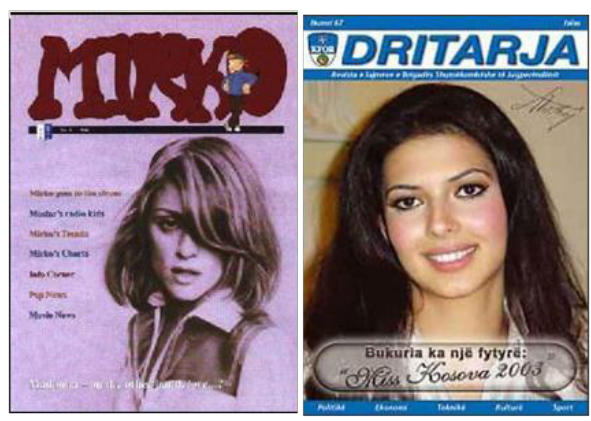

German magazines MIRKO and DRITARJA

Figure 9. Magazines

In February 1999, soldiers of the 4th Psychological Operations Group deployed to establish and form the Joint Psychological Operations Task Force (JPOTF) in support of Joint Task Force Noble Anvil. Their mission was to get the message of truth to the diverse masses, which included Serb military, police forces in Kosovo, and the civilian population in Belgrade as well as in the small towns and villages throughout the remaining of Serbia, and to Kosovo refugees in Albania and Macedonia. During the 78-day air campaign, the JPOTF developed over 40 different leaflets. Over 100 million of these leaflets were box dropped by MC-130H Combat Talon aircraft from the 7th Special Operations Squadron over 
Serbia. 4.5 million more leaflets were distributed by F-16 and B-52 aircraft via MK-129 leaflet bombs ${ }^{14}$.

The JPOTF also produced radio and television programmes in Serbian and Albanian which were broadcast by EC-130E Commando Solo aircraft of the $193^{\text {rd }}$ Special Operations Wing. Three EC-130E were deployed from Harrisburg, Pennsylvania to a base in Brindisi in Italy as a direct response to persistent hostile Bosnian - Serb radio and television propaganda from the Karadzic faction. EC$130 E$ Command Solo aircraft transmitted both radio and television broadcasts, blanketing Belgrade and Northern Yugoslavia, Kosovo, and southern Serbia with "Allied Voice Radio and Television". The Command Solo aircraft continued to fly and broadcast "Allied Voice and Television" even after the air campaign ended on 9 June, 1999.

In 1999, Radio KFOR was the only radio station in the Pristina area. After 2001, the station had to face fierce competition from a myriad of newly founded local radio stations.

The German, French, Belgian, Italian and Spanish contingents also conducted PSYOP activities in support of their missions. Both German KFOR in the south (MNB South) and French KFOR in the north (MNB North) produced their own printed magazines: Dritarja/Prozor (German AOR) and Bonjour (French AOR).

In 1994, French forces were unable to conduct PSYOP because of lack PSYOP specialists to advise the commanders in the field, and no printing facilities to communicate with the local population or factions. Moreover, they misunderstood and mistrust the motives of the US PSYOP personnel who dominated the early effort in Bosnia. Over time, the French began to accept increased US PSYOP support, including a PSYOP radio station in Mostar and a small group of US tactical PSYOP soldiers who disseminated materials. In addition, they decided to develop their own capability in order to influence the PSYOP context more directly. This led to the establishment of a French-run PSYOP radio station and creating, together with Spanish and German PSYOP, a print product development capability in Mostar.

14 http://www.psywarrior.com/kosovo.html, 20 February 2017. 
Belgium had a small PSYOP Support Element unit called the Information Operations Group consisting of about 30 regular military personnel and selected reservists as needed. The first Belgians operation were in late 1999 in Kosovo where they installed a PSYOP radio station called "Radio Horizon" in the Belgian camp called "Center City" at the French-occupied section of Kosovo in Leposavic.

The Italian contingent developed a comic strip featuring Bugs Bunny to raise children's awareness of mines.

During the Bosnia and Kosovo war, the technologies used shifted from pamphlets and leaflets to comics and television programmes.

\section{Psychological Operations during the Persian Gulf War (1991)}

The Persian Gulf War was triggered by Iraq's invasion of Kuwait on August 2, 1990. The allied coalition's military offensive against Iraq began on January 16-17, 1991. Persian Gulf War strategic and tactical field level psychological operations supported the goals and conditions set forth by coalition leaders upon an international scale.

Psychological operations played a key role in the destruction of enemy morale and contributed to the large scale surrender and desertion of Iraqi soldiers. According to statements by an Iraqi division commander, PSYOP leaflets were a great threat to troop morale, the second in terms of significance after the Coalition bombing campaign. During this war, PSYOP units dropped over 29 million leaflets to encourage Iraqi soldiers to surrender, usually by stressing the inevitability of their defeat. Estimates show that nearly $98 \%$ of all Iraqi prisoners acknowledged having seen a leaflet, $88 \%$ said they believed the message and 70\% said the leaflets affected their decision to surrender. Of the estimated 100000 soldiers who deserted or surrendered, many were found carrying leaflets in their hands or carrying them in their clothes.

The principal method for leaflet dissemination was through aerial delivery. Prior to combat operations, leaflets were disseminated by C-130 aircraft. Specially configured M-129E1 leaflet bombs were later utilised effectively by B-52, F-16 and F/A-18 aircraft. 


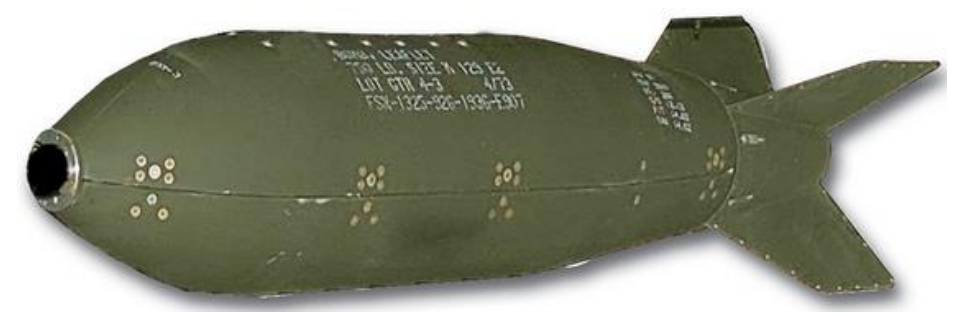

Source: https://thaimilitaryandasianregion.wordpress.com/2016/06/05/.

Figure 10. M129E1/E2 Leaflet Bomb

The M-129 is capable of holding approximately 60,000 to 80,000 leaflets.

The PSYOP radio network, "Voice of the Gulf" broadcast from 19 January 1991 until the end of the war. "Voice of the Gulf" was the most reliable source of war news available to the Iraqi soldier throughout operation "Desert Storm". Moreover, sixty six PSYOP loudspeaker teams provided tactical support for every major ground unit throughout the ground war.

Leaflet and loudspeaker operations continued non-stop during the air and ground phases of the conflict. Psychological operations played a key role in the destruction of enemy morale and contributed to the large scale surrender and desertion of Iraqi soldiers.

After the Persian Gulf War, Pentagon experts agreed on one thing: the action was a psychological weapon that does not kill, but was psychologically shocking and it was seen as an important factor in increasing the ability of combat troops and at the same time affecting a significant reduction in losses on both sides.

\section{Psychological Operations in Iraq 2001-2011}

President George W. Bush announced the opening of the second Gulf War at 2215 on 19 March 2003 just 90 minutes after the deadline for Saddam to exile himself and his sons from Iraq. Operation Iraqi Freedom aircrews dropped more than 2 million leaflets over 29 military and civilian targets on 21 March. The mix consisted of 17 different leaflets. The Coalition previously dropped eleven of the 
leaflets during the "No-Fire Zone" warning phase of the campaign ${ }^{15}$. Leaflets dropped over Iraq and radio broadcasts urging civilians to stay in their homes and away from military forces.

The US PSYOP teams in Iraq were the largest of any conflict including 11 companies and almost 1,000 personnel in Iraq or in support roles in the US, according to Lt Col Glenn Ayers commander of the 9th Psychological Operations Battalion ${ }^{16}$.

More than 150 million leaflets have been produced at Fort Bragg and distributed throughout Afghanistan and Iraq since September 2001.

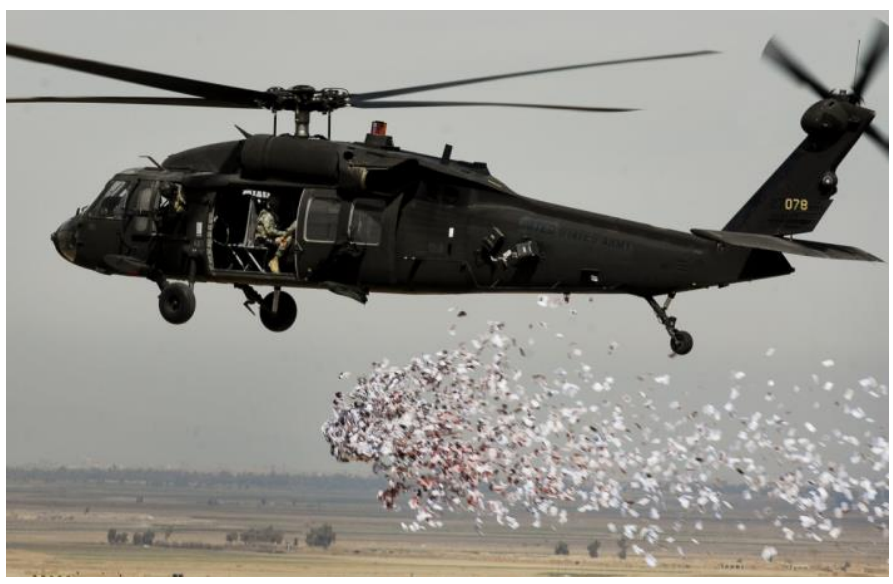

Source: https://upload.wikimedia.org.

Figure 11. UH-60 PSYOP leaflet drop near Hawijah in Iraq - 06 March 2008

The most famous leaflet of the war in Iraq is the U.S. military issued illustrated deck of cards depicting the 52 "most wanted" members of the Saddam Hussein regime delivered to thousands of U.S. troops in the field. They printed the same data on posters and leaflets for the Iraqi public. Four aces showed the most wanted fugitives: Saddam Hussein, his sons Uday and Qusay, and the presidential secretary Abid Hamid Mahmud Al-Tikriti.

15 H.A. Friedman, Psychological Operation in Iraq: Operation Iraqi Freedom, 2003, https:// www.psywar.org/content/opiraqifreedom, 04.02.2017.

16 J. Krane, US units try to win Iraqi hearts and Minds, http://www.kvue.com/sharedcontent/ iraq/military/060503cciraqhearts.8d028054.htm, 30 January 2017. 


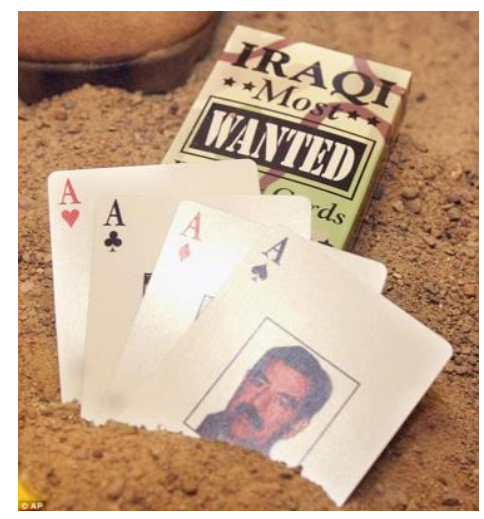

Source: http://www.dailymail.co.uk .

\section{Figure 12. Deck of "Most Wanted Iraqi" playing cards}

In addition to leafleting, the other PSYOP mass medium used heavily by the Coalition was the radio. The coalition broadcast from fixed transmission towers as well as from the flying airborne broadcast platform, the EC-130E aircraft Commando Solo. Local PSYOP radio stations were also set up outside the major population centres. For instance, the UK PSYOP radio station, "Radio Nahrain" (Two Rivers), an FM radio station was established on the outskirts of Basra. Additionally setting up its own radio transmitters, the Coalition attempted electronically to jam Iraqi radio stations, in order to gain a monopoly on the information available to the Iraqi people through this medium.

One of the more innovative means used by Coalition PSYOP in the build-up to "Iraqi Freedom" was the use of mobile phone text messaging and e-mails sent directly to key decision-makers in the Iraqi regime. At the start of 2003, there were only 60 internet cafes in Iraq, and the connection fee of US \$25 per home was beyond the reach of most ordinary Iraqis. Also, the Iraqi regime was wary of allowing access to the internet throughout Iraq. So, while many ordinary Iraqis did not have access to the internet, most of the Baath Party leadership did, and the Coalition used this means specifically to outline each the cost of their continued support for Saddam both for Iraq collectively and for themselves personally ${ }^{17}$.

17 S. Collins, Mind Games, http://www.nato.int/docu/review/2003/Wake-Iraq/Mind-games/ EN/index.htm, 12.02.2017. 
I would like to emphasise that the armed intervention in Iraq was the biggest operation abroad in which the Polish army participated after the Second World War. In September 2003, commanded by a Polish general, the Multinational Division Central-South (MND-CS) took over responsibility for one of the zones in Iraq. The Polish Military Contingent (first rotation) deployed to Iraq with approximately 2300 soldiers and took over an area of responsibility (AOR) in the Central-South sector.

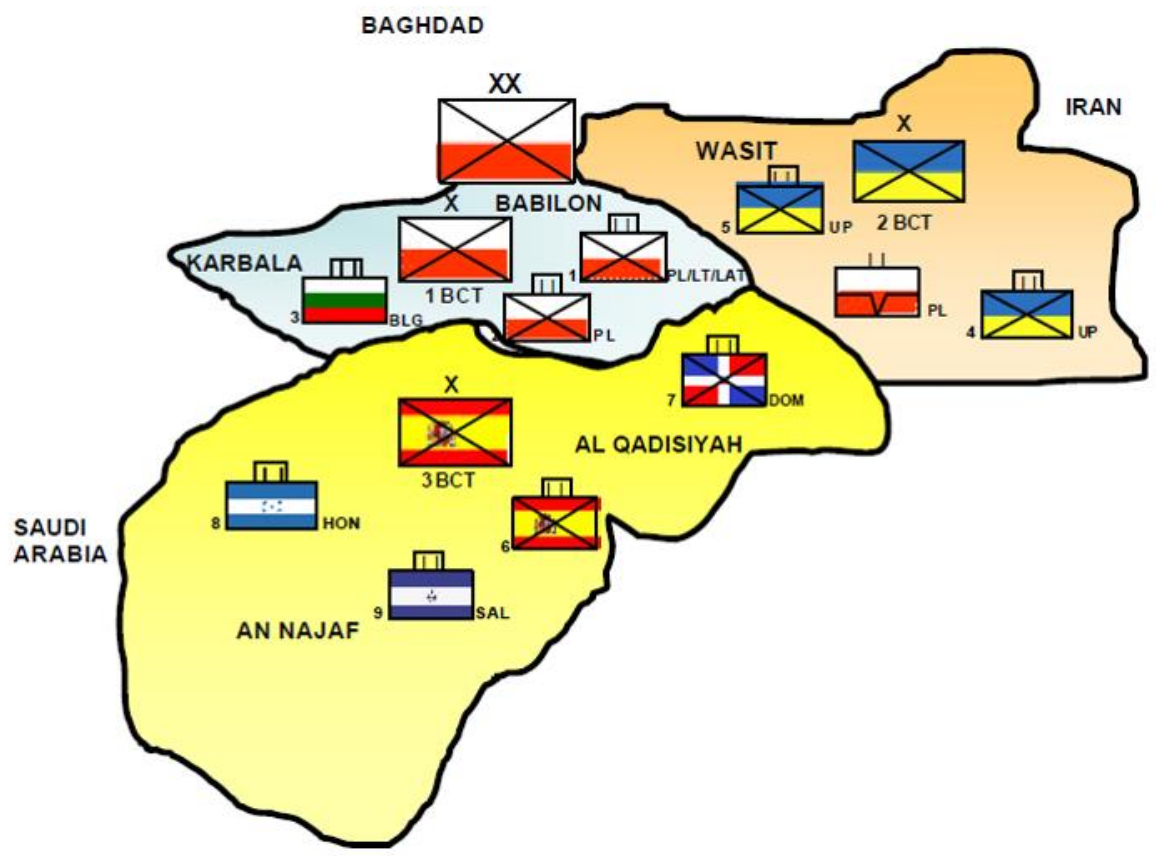

Source: Z. Antczak, The multinational division: is it viable in peace enforcement operations? U.S. Army War College, Pennsylvania 2005, p. 5.

Figure 13. MND-CS Area of Responsibility in 2003

What I also found important was the role of psychological operations elements during the stabilisation operation. At the beginning, the PSYOP contingent in Multinational Division Central-South consisted of the branches shown on the diagram below. 


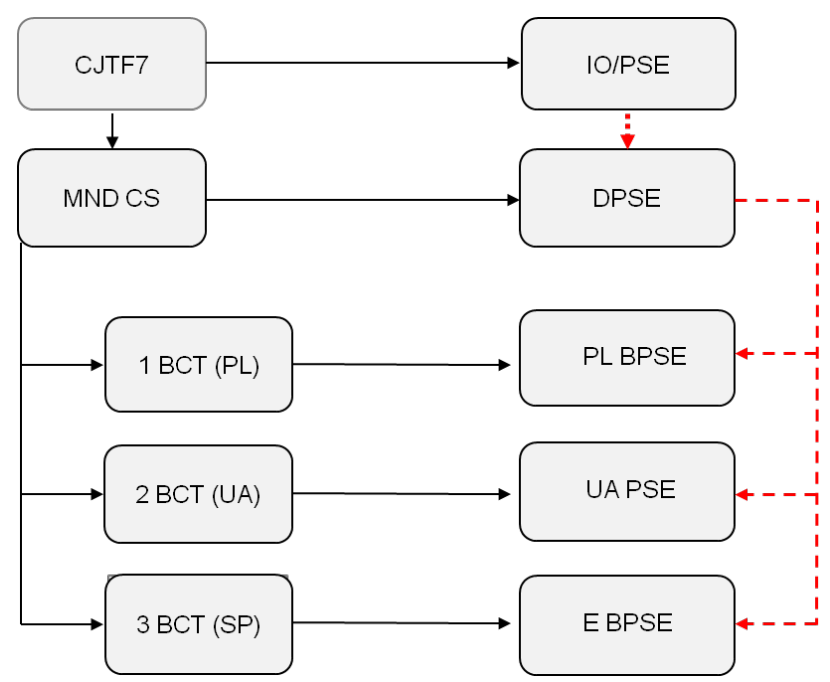

Figure 14. PSYOPS structure in MND-CS

The structure and tasks of the PSYOP contingent in MND-CS had been changing during the operation. However, the main role in MND-CS was played by PSYOP elements detached from the Central Psychological Operations Group. This unit is located in Bydgoszcz and officially began functioning on 10 April 2003.

The most important role in the field of psychological influence in MND-CS was played by the Divisional Psychological Support Element (DPSE). DPSE was a MND CS staff element and was subordinate to the G-3 chief. DPSE consisted of three functional cells as shown in the diagram below.

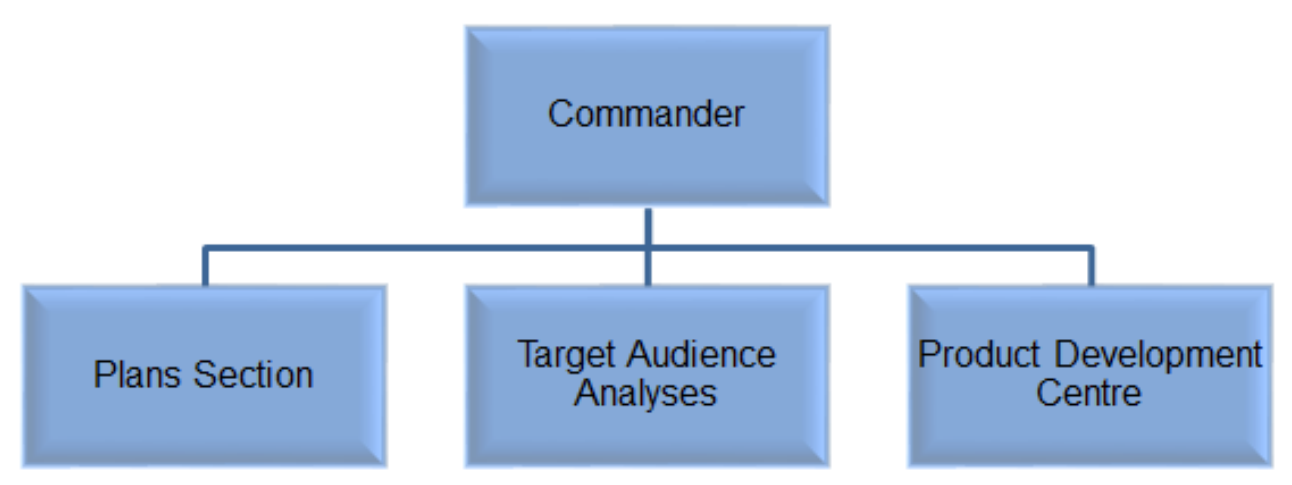

Figure 15. Structure of Polish DPSE 
DPSE equipment included: mobile print facility, risograph, audio/video production studio, media $\left(\mathrm{OSINT}^{18}\right)$, monitoring studio and off-road vehicle SCORPION.

Hence, the Division Psychological Support Element conducted psychological operations in order to change or reinforce the behaviour of local governing institutions, organisations, groups, and individuals in MND CS AO.

The Polish psychological operation in Republic of Iraq was carried out in the framework of the thirteen main programmes in the diagram below.

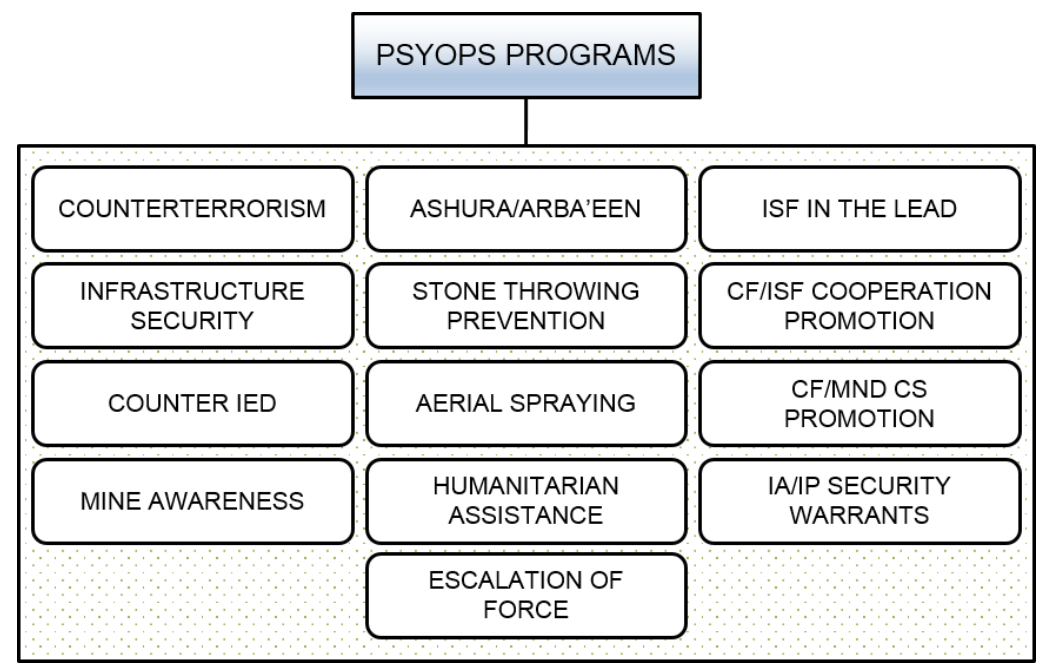

Figure 16. Polish PSYOPS programs in Iraq

Polish PSYOP specialists identified the main objects of impact:

- Shiite population,

- people of other ethnic and religious groups,

- Iraqi local leaders,

- religious leaders,

- representatives of local government,

- local police,

- refugees and immigrants,

- paramilitary organisations.

18 OSINT - Open Source of Information. 
During the Polish involvement in Iraq, the psychological operation element tested the entire spectrum of psychological techniques to spread from direct messages through electronic, radio and TV broadcasts, websites and the discharge of leaflets from helicopters and airplanes.

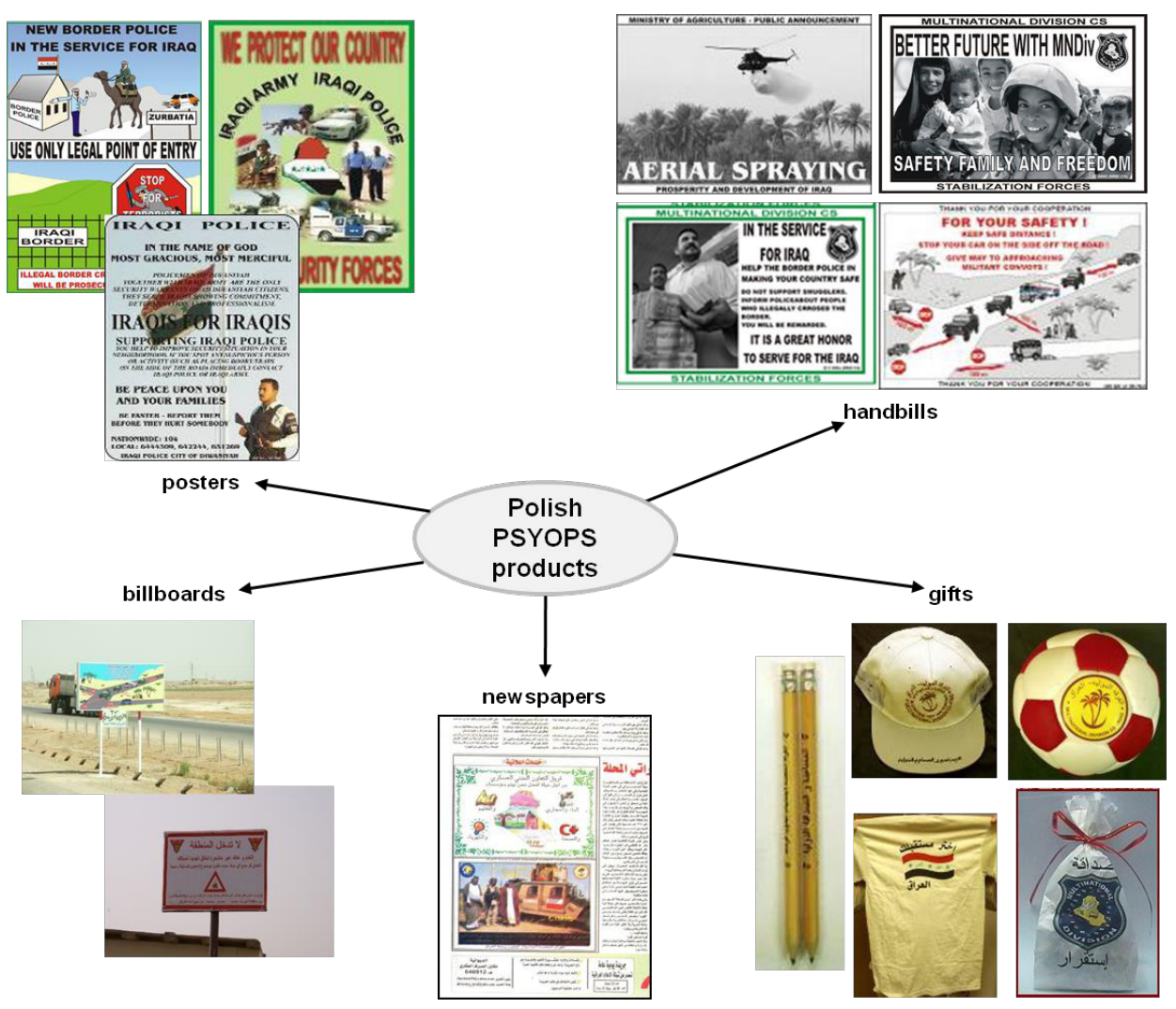

Figure 17. Polish PSYOPS products

One of the key recommendations for psychological influence was the recognition of direct communication as the most effective form of this kind of action.

During one rotation, the Polish Contingent DPSE conducted $^{19}$ :

- 30 psychological actions,

- 3 leaflet airdrops,

19 Data from VI Rotation of the Polish Contingent. 
- 2 surveys in WASIT province,

- 2 events in 8 Iraqi Army Division,

- took part in the operation EAGLE II,

- 10 combat patrols (MSR TAMPA \& escort for rotation convoy).

For example, from January till June 2006, over 898000 PSYOPS products (handbill, leaflet, poster, comic book, billboard, warning sign, press publication, multimedia (TV) spot, announcement, soccer ball, T-shirt, mascot, notebook, pencil, etc.) were disseminated by the Polish DPSE.

The Polish PSYOP element during the VI rotation conducted operations according to OPORD Multinational Corp - Iraq (MNC-I), which determined four main psychological objectives:

- increasing support for the local governments of Wasit and Quadisiyah;

- reducing the effectiveness of the Anti-Iraqi Forces (AIF);

- increasing support for the Coalition;

- increasing support for economic development in the MND CS area of operation (AO).

Psychological Operations conducted in MND CS AO resulted in a positive or neutral attitude of the majority of the population towards Iraqi Security Forces and Coalition Forces, and increased the number of tips concerning terrorist activities given by local society and peaceful ASHURA and ARBA'EEN observances.

\section{Conclusion}

Psychological operations were carried out on a larger or smaller scale by both sides in all military conflicts after World War II. The conclusions of the analysis indicate that the United States is the undoubted leader in the global environment of psychological operations. This results from the repeated involvement of the US in military activities in various parts of the world and existing potential to conduct psychological operations. US psychological operations are characterised by the continuous development of their potential in all possible aspects. 
The Polish Army also noted the need to develop capabilities to conduct psychological activities and, therefore, the Central Psychological Operations Group was created. Soldiers from this unit participated in the operation "Iraqi Freedom" and they gained knowledge and experience, which was then used in Afghanistan.

Furthermore, a successful information campaign contributes to building and preserving public support for the operation. Thus, the successful use of information can help the commander achieve operational goals by influencing parties, resolving crises, defusing misunderstandings, and correcting misperceptions.

Nowadays, there is no doubt that the influencing of the opponent through psychological impact has become one of the key ways of fighting. Therefore, psychological operations will include activities before, during and after major combat operations. It will serve for systematically weakening the enemy's morale, aiming to degrade the functioning of society, and ultimately leading to the collapse of state structures and the functioning of victory.

In conclusion, a psychological operation has the potential to be the most powerful weapon in the military's arsenal. It targets the mind and influences decision makers. The effect of military operations can be magnified by PSYOP through the modification of the foreign target audience's behaviour. Psychological operations as long term activities require continuity of efforts in order to achieve determined objectives.

\section{References}

AAP-06 (2014) NATO Glossary Terms and Definitions, NSA, 29 April 2014.

Allied Joint Doctrine for Information Operations AJP- 3.10 (A), December 2015.

Allied Joint Doctrine for Psychological Operations AJP-3.10.1(B), September 2014.

Antczak Z., The multinational division: is it viable in peace enforcement operations?, U.S. Army War College, Pennsylvania 2005.

Collins S., Mind Games, http://www.nato.int/docu/review/2003/Wake-Iraq/Mindgames/EN/index.htm.

Friedman H.A., Psychological Operation in Iraq: Operation Iraqi Freedom, 2003, https:// www.psywar.org/content/opiraqifreedom. 
Harter L.D., Sullivan J., Propaganda Handbook, 20 ${ }^{\text {th }}$ Century Publishing Company, Washington 1953.

Hosmer S.T., Psychological effects of. U.S. Air Operations in Four Wars 1941-1991: Lessons for U.S. Commanders, Santa Monica, California 1996.

Jacobson M.R., Tactical PSYOP Support to Task Force Eagle, The National Defence University, 1997.

Joint Publication JP-3-13.2 Military Operation Support Operations, 07 January 2010, Incorporating Change 1, 20 December 2011.

Krane J., US units try to win Iraqi hearts and Minds, http://www.kvue.com/sharedcontent/ iraq/military/060503cciraqhearts.8d028054.htm.

Operacje psychologiczne DD/3.10.1 (A), Sztab. Gen., Warszawa 2010.

Whitley G.L., PSYOP operations in the $21^{\text {th }}$ century, U.S. Army War College, Carlisle Barracks, Pennsylvania 2000.

PsyWar: an exhibition of Korean War propaganda leaflets, http://www.korea.net/ NewsFocus/Society/view?articleId=81778.

http://timyoho.net/BVApage/7thPsyOp/Merkle-KIA-Accounts.html.

http://www.psywarrior.com/bosnia.html.

http://www.psywarrior.com/kosovo.html. 